\author{
Vabischevich M. \\ Dedov 0., \\ Glitin 0.
}

\title{
NUMERICAL-EXPERIMENTAL RESEARCH OF TECHNOLOGICAL EOUIPMENT FOUNDATIONS IN DYNAMIC IMPACT CONDITIONS
}

При проектуванні нових виробничих цехів чи реконструкиї існуючих гостро постає питання врахування не тільки всіх статичних навантажень, але і можливих динамічних впливів, викликаних нестаціонарною роботою технологічного обладнання. В роботі на прикладі обстеження технічного стану виробничої будівлі, конструкиї якої зазнають динамічного впливу від дї технологічного обладнання, розглянуто експериментально-чисельний підхід до моделювання розрахункової ситуачї, визначення причин виникнення деформацій та вибору способу підсилення. Об'єктом досліджень є прощес динамічного деформування окремо розташованого фундаменту технологічного обладнання - деревообробного верстату, в умовах діючого виробництва. Дослідження направлено на пошук конструктивного вирішення проблеми передачі вібрацій від двигунів верстату через власний фундамент та грунтову основу на фундаменти та несучі елементи споруди виробничого цеху. Основна ідея експериментально-чисельного підходу - ие порівняння результатів чисельних та натурних вимірів параметрів коливань. Чисельний аналіз виконаний на основі скінчено-елементного розрахунку за допомогою сучасних програмних комплексів, натурні виміри - це записані за допомогою сейсмографа віброграми, на основі яких побудовані спектри коливань споруди, за якими визначені домінуючі частоти коливань. Явища внутрішнього резонансу споруди, виявлені на основі порівнянь результатів, дозволили чітко сформулювати причини появи тріщин в конструктивних елементах.

Результати досліджень використані при проектуванні нової та відновленні існуючих баз технологічного устаткування під час капітального ремонту споруди цеху та технічного переоснащення виробництва.

Застосування експериментально-чисельного підходу для аналізу вихідних даних при проектуванні чи реконструкцї споруд, за наявності нестаціонарних вібродинамічних навантажень, дозволяє побудувати математичну модель максимально наближену до реальної. Отримані результати досліджень можуть бути використані при розробщі методик і технологій діагностування несучих $i$ огороджувальних конструкцій споруд, що перебувають під впливом динамічного навантаження.

Ключові слова: обстеження споруди, вібраційна діагностика, власні частоти коливань, тріщиноутворення, динамічне навантаження, скінченно-елементна модель.

Received date: 10.06.2019

Accepted date: 27.06.2019

Published date: 31.10 .2019
Copyright (C) 2019, Vabischevich M., Dedov O., Glitin O. This is an open access article under the CC BY license (http://creativecommons.org/licenses/by/4.0)

\section{Introduction}

When designing new production workshops or reconstructing existing ones, the urgent issue is to take into account not only all static loads, but also possible dynamic effects caused by unsteady operation of technological equipment. Transfer of technological loads, including the dynamic component, can occur both through the ground elements of the frame (beam cells, floor slabs), and through the soil base. In the case of designing foundations for new technological equipment, in the conditions of the existing production, this task is much more complicated, since the number of unknowns in the source data increases significantly.

A number of works are devoted to studying the dynamic behavior of building structures under the influence of external factors. So, in [1], the results of measurements of dynamic effects and numerical calculations of vibration isolation systems are presented. In [2], a method is proposed for assessing the influence of railway vibration on adjacent buildings and the propagation of such vibration through a soil mass. The work [3] presents the results of a numerical study of the anti-vibration barrier; it is used to reduce the dynamic effect on the foundations of a historic building from traffic, the proposed model and methodology for taking into account the dynamic parameters of the structure and vibration damper. Experimental studies based on measurements of accelerations are given in [4]. On the basis of the constructed vibration spectrum, the natural vibration frequencies are determined. The technique described can be used in the study of more complex dynamic systems [5]. Measurements of the dynamic characteristics of systems for the purpose of diagnosing and monitoring existing defects in metal structures are presented in [6]. The methodology for the application of experimental studies of vibration and their processing is presented. The improvement of the calculation model based on the obtained dynamic characteristics is proposed. The application of the method to nonlinear active vibration control systems is presented in [7]. According to the authors, this method allows to get a result without significant 
knowledge about the dissipative properties of the system, of course, it gives advantages and reduces the time for research. On measuring instruments, it is possible to use different types of sensors. So, in [8], acceleration measurement sensors are used. The remote measurement given in [9] is based on the use of laser and optical devices. And the use of an vibration sensor based on optical fiber is proposed in [10].

Despite a significant number of publications and a wide range of tasks that are considered in them, the study of the behavior of building structures under the influence of dynamic load is an important area of both theoretical and experimental research.

The object of research presented in the current work is the process of dynamic deformation of a separately located foundation of technological equipment - a woodworking machine, in the conditions of existing production.

The aim of research is in finding a constructive solution to the problem of transferring vibrations from the machine's engines through its own foundation and soil base to the foundations and supporting elements of the building of the production workshop.

\section{Methods of research}

Experimental studies were carried out under the operating conditions of a construction facility - the building of a production workshop, during an instrumental examination of its technical condition. The main task of the technical examination was determination of the cause of cracks (including through cracks) in the external and internal longitudinal walls. During the examination, significant vibration effects from technological equipment (winding machines of wooden shavings) on the supporting elements of the building were revealed.

The building was examined, one-story, in the plan of a rectangular shape with overall dimensions of $53.865 \times 17.70 \mathrm{~m}$. The height of the building to the lower zone of the coating beams is $4.535-5.10 \mathrm{~m}$. According to the structural system, the building is wall-mounted with longitudinal load-bearing walls reinforced by pilasters on which precast reinforced concrete tees are supported beams over which ribbed slabs are arranged. Foundations - tape, solved from prefabricated foundation wall blocks. The base is represented by clay loess soils.

To carry out measurements and obtain real values of the vibrations of various points of the structure, the ZET 048C seismograph (Russia) was used, the technical data of which are given in Table 1.

Tahle 1

ZET 048C accelerometer technical specifications

\begin{tabular}{|l|l|}
\hline Type of sensors & differential \\
\hline The number of measured coordinates & $3(X, Y, Z)$ \\
\hline Measurement parameter & vibration acceleration \\
\hline Working range, $\mathrm{Hz}$ & from 0.3 to 400 \\
\hline Sensitivity & no more than $10^{-5} \mathrm{~m} / \mathrm{s}^{2}$ \\
\hline The main relative error, $\%$ & no more than \pm 10 \\
\hline Working temperature, ${ }^{\circ} \mathrm{C}$ & from -30 to +50 \\
\hline
\end{tabular}

The research consisted in the experimental measurement of the motion parameters of the elements of the supporting structures in real time with their subsequent processing and determination of the dynamic characteristics of such elements and the structure as a whole.
As a dynamic criterion for assessing the state of loadbearing structures, the values of natural vibration frequencies were used.

To determine the dynamic parameters, six control points were selected, a list of which is given in Table 2 .

Table 2

Location of static monitoring control points

\begin{tabular}{|c|c|c|c|c|}
\hline $\begin{array}{c}\text { Con- } \\
\text { trol } \\
\text { point }\end{array}$ & $\begin{array}{c}\text { Control } \\
\text { point } \\
\text { location }\end{array}$ & $\begin{array}{l}\text { Description of the structural } \\
\text { element }\end{array}$ & $\begin{array}{c}\text { Number of } \\
\text { measurement } \\
\text { sensors }\end{array}$ & $\begin{array}{l}\text { Para- } \\
\text { meter }\end{array}$ \\
\hline P1C1 & 3-B & $\begin{array}{c}\text { Foundations of technological } \\
\text { equipment }\end{array}$ & $3(X, Y, Z)$ & \multirow{6}{*}{$\begin{array}{l}\text { Vibra- } \\
\text { tion } \\
\text { accele- } \\
\text { ration }\end{array}$} \\
\hline P1С2 & $2-B$ & Column Center1 & $3(X, Y, Z)$ & \\
\hline P1C3 & 9-B & Column Center 2 & $3(X, Y, Z)$ & \\
\hline P1C4 & $2-\mathrm{V}$ & Column Center 3 & $3(X, Y, Z)$ & \\
\hline P1C5 & $3-A$ & Column workshop 1 & $3(X, Y, Z)$ & \\
\hline P1C6 & $3-B$ & Column workshop1 & - & \\
\hline
\end{tabular}

The recorded vibration programs of the building vibrations at the control points were to be processed using the ZETLAB SEISMO software using spectral analysis using the discrete Fourier transform method.

The obtained spectra were analyzed in order to determine the numerical values of the vibration frequencies corresponding to the main peaks in the spectrograms and are a consequence of the recall of the design to external vibration sources.

The calculated finite element model of the structure (hereinafter referred to as FEM) is adopted in accordance with the well-known rules of building mechanics, taking into account the availability of foundations of technological equipment (Fig. 1). The approximation of the soil massif was performed using spatial 8-node finite elements of type No. 276.
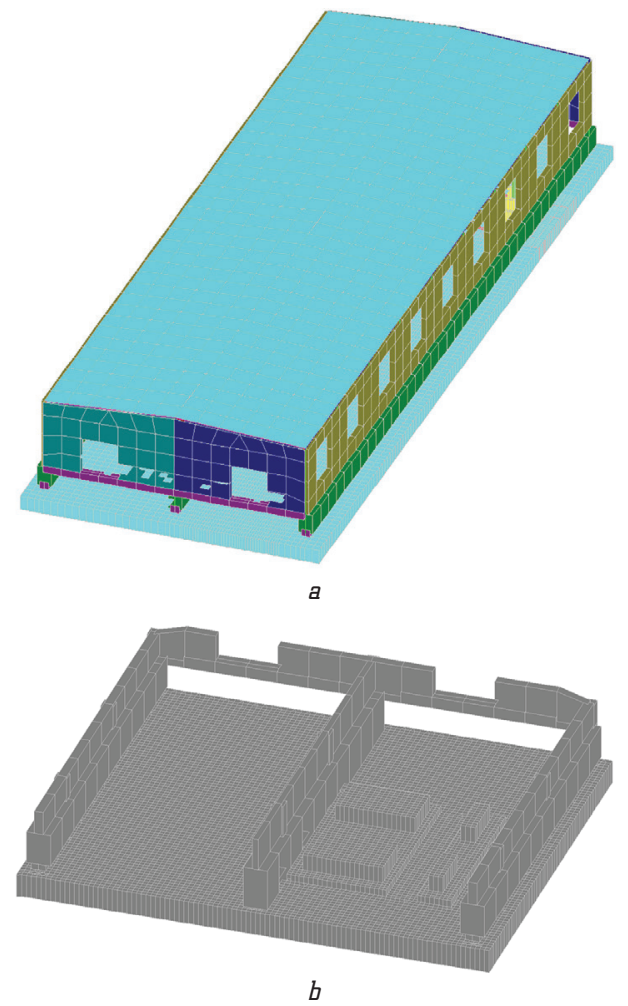

Fig. 1. FEM of the construction of the production workshop: $a$ - general view of the building; $b$ - FEM fragment with equipment foundation 
Static and modal analysis of the structures was performed in a nonlinear statement using the Scad Office and Lira CAD systems, based on the use of the finite element method.

\section{Research results and discussion}

During field measurements of structural vibrations, vibration records (Fig. 2) were obtained at control points. Vibrations recorded show that the intensity of vibrations on the structure increases with decreasing distance to the sources of technological impact.

The obtained spectra were analyzed in order to determine the numerical values of the vibration frequencies corresponding to the main peaks in the spectrograms and are a consequence of the recall of the design to external vibration sources.

As a result of the analysis of vibration records, the spectral distribution of vibration frequencies at each control point is obtained.

So, at the control point $\mathrm{P} 1 \mathrm{C} 1$ (foundations of technological equipment) in the frequency range from 0 to $15 \mathrm{~Hz}$, a number of peaks can be distinguished (Fig. 3), which correspond to vibration frequencies of 3.90, 4.02, 7.81, 8.06 and 11.73 and $12.08 \mathrm{~Hz}$, respectively. Given the close proximity of the control point to the sources of vibration excitation, it can be argued that the dynamic effect on the frame of the supporting structures is characterized by precisely these values of the vibration frequencies.

The spectrum of vibrations at the control point T1K2 (central reinforced concrete column of the supporting frame of the structure) has distinct frequency peaks, the values of which are 3.90 and $4.02 \mathrm{~Hz}$, respectively (Fig. 4). Obviously, it is these frequency values that are the cause of the vibrations and the cracking process of the wall; in addition, the superharmonics of these peaks of the vibration frequencies 7.81, $8.06 \mathrm{~Hz}$ and 11.73 and $12.08 \mathrm{~Hz}$, respectively, are clearly distinguished.

According to the calculation results, it was found that the frequencies of the 3rd form of natural vibrations $(3.67 \mathrm{~Hz})$ actually coincide with the forced ones. It is these frequency values that led to the appearance of a wall structure of an industrial building close to the resonant regime of vibrations.

Based on the results of numerical and experimental studies, a new design of the technological founda- tion was designed - a massive, complex section reinforced concrete slab with a plan size of $6850 \times 7000 \mathrm{~mm}$ (Fig. 5). The foundation is designed to accommodate two woodworking machines, the parameters of the dynamic impact of which are calculated on the basis of field measurements.

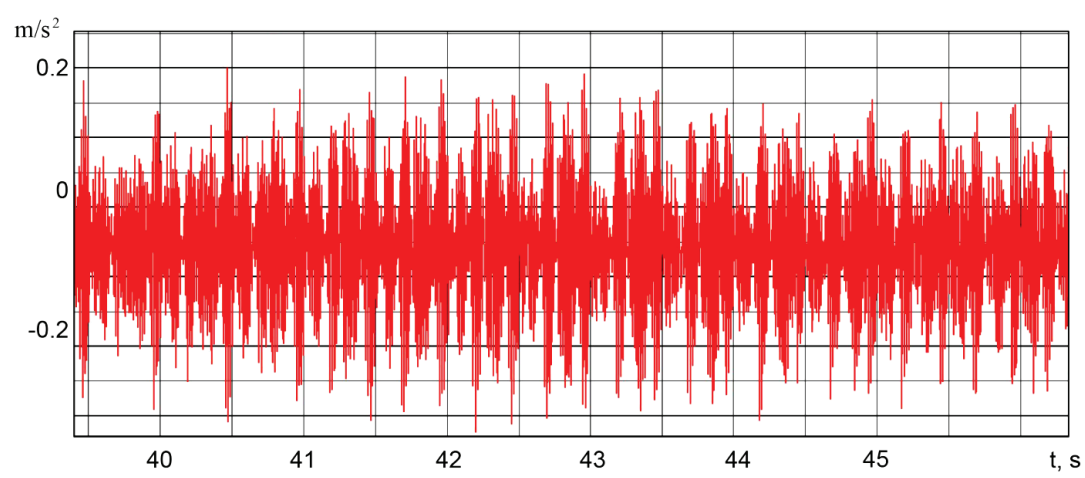

Fig. 2. Vibration records in the control point P1C1

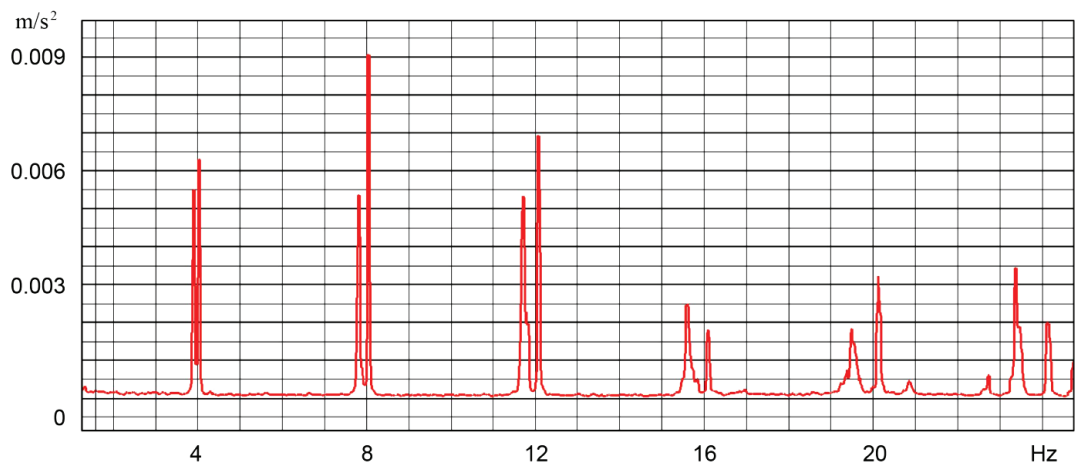

Fig. 3. The frequency spectrum of the vibrations P1C1 in the frequency range from $\mathrm{O}$ to $20 \mathrm{~Hz}$

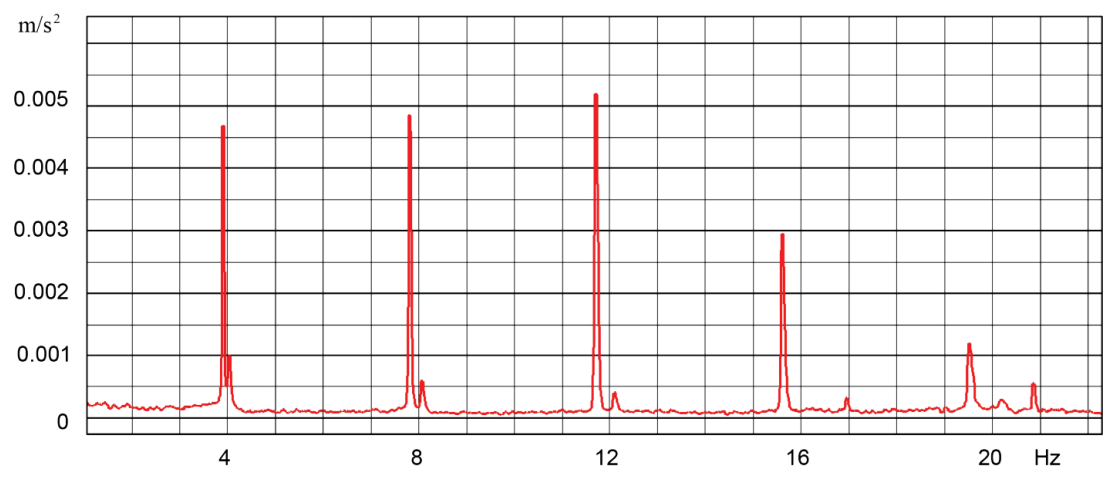

Fig. 4. The frequency spectrum of the vibrations P1C2 in the frequency range from $\mathrm{O}$ to $20 \mathrm{~Hz}$
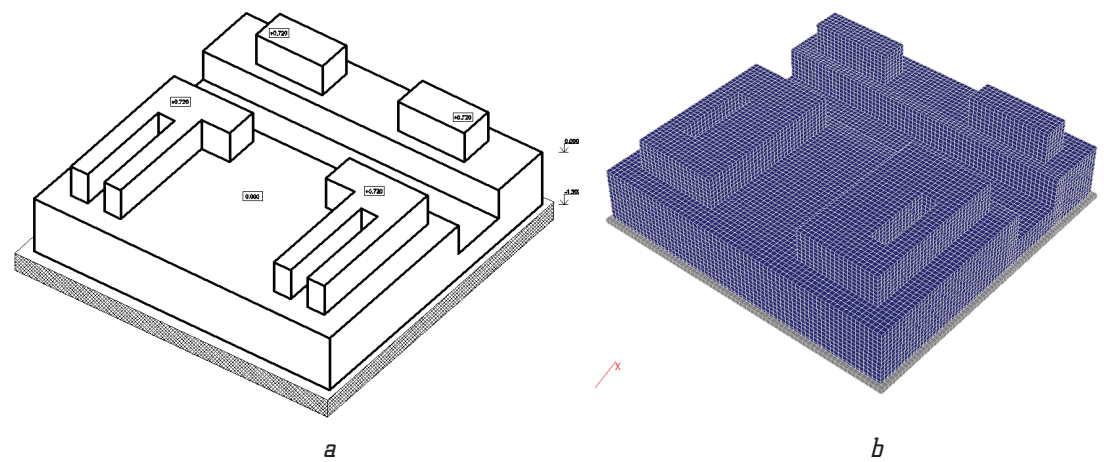

Fig. 5. The foundation construction of technological equipment: $a$ - graphic spatial model; $b$ - finite element model using volumetric finite elements 
The dynamic structural analysis is performed using two methods - based on a schedule using its own forms of vibration and direct integration of the equation of motion. FEM foundation is built using volumetric 8-node finite elements (FE). The obtained values of the natural vibration frequencies of the first 10 forms (from 0.5 to $1.5 \mathrm{~Hz}$ ) indicate the absence of a threat of occurrence of vibrations close to the resonance mode. Using the direct method of integration of the equation of motion, the calculated stress-strain state of the structure and the appropriate parameters of the reinforcement are selected taking into account the presence of dynamic effects.

\section{Conclusions}

According to the results of measuring the dynamic parameters of the motion of the load-bearing elements of the construction of the production workshop under the influence of technological equipment, vibration frequencies of 3.90 and $4.02 \mathrm{~Hz}$ are determined. Comparison of the results of a numerical modal analysis of the structure with field measurements shows the presence of an operating mode close to resonance, which caused the appearance and propagation of cracks in the walls of the building (Fig. 1).

The results of a numerical experimental study of the existing foundation of technological equipment are used for FE-modeling of the construction of a new foundation for similar equipment.

\section{References}

1. Vladimir, S. (2017). Numerical Estimation of Precision Equipment Vibration Isolation System. Procedia Engineering, 176, 363-370. doi: http://doi.org/10.1016/j.proeng.2017.02.333

2. Connolly, D. P., Kouroussis, G., Giannopoulos, A., Verlinden, O., Woodward, P. K., Forde, M. C. (2014). Assessment of railway vibrations using an efficient scoping model. Soil Dynamics and Earthquake Engineering, 58, 37-47. doi: http://doi.org/10.1016/ j.soildyn.2013.12.003

3. Cacciola, P., Banjanac, N., Tombari, A. (2017). Vibration Control of an existing building through the Vibrating Barrier. Procedia Engineering, 199, 1598-1603. doi: http://doi.org/10.1016/ j.proeng.2017.09.065
4. Kavyanpoor, M., Shokrollahi, S. (2019). Dynamic behaviors of a fractional order nonlinear oscillator. Journal of King Saud University - Science, 31 (1), 14-20. doi: http://doi.org/10.1016/ j.jksus.2017.03.006

5. Giagopoulos, D., Arailopoulos, A., Dertimanis, V., Papadimitriou, C., Chatzi, E., Grompanopoulos, K. (2017). Computational Framework for Online Estimation of Fatigue Damage using Vibration Measurements from a Limited Number of Sensors. Procedia Engineering, 199, 1906-1911. doi: http://doi.org/10.1016/ j.proeng.2017.09.424

6. Bendjama, H., Bouhouche, S., Boucherit, M. S. (2012). Application of Wavelet Transform for Fault Diagnosis in Rotating Machinery. International Journal of Machine Learning and Computing, 2 (1), 82-87. doi: http://doi.org/10.7763/ ijmlc.2012.v2.93

7. Yamamoto, G. K., da Costa, C., da Silva Sousa, J. S. (2016) A smart experimental setup for vibration measurement and imbalance fault detection in rotating machinery. Case Studies in Mechanical Systems and Signal Processing, 4, 8-18. doi: http:// doi.org/10.1016/j.csmssp.2016.07.001

8. Jia, Y., Seshia, A. A. (2014). An auto-parametrically excited vibration energy harvester. Sensors and Actuators A: Physical, 220, 69-75. doi: http://doi.org/10.1016/j.sna.2014.09.012

9. Lezhin, D. S., Falaleev, S. V., Safin, A. I., Ulanov, A. M., Vergnano, D. (2017). Comparison of Different Methods of Noncontact Vibration Measurement. Procedia Engineering, 176, 175-183. doi: http://doi.org/10.1016/j.proeng.2017.02.286

10. Gianti, M. S., Prasetyo, E., Wijaya, A. D., Berliandika, S. Marzuki, A. (2017). Vibration Measurement of Mathematical Pendulum based on Macrobending-Fiber Optic Sensor as a Model of Bridge Structural Health Monitoring. Procedia Engineering, 170, 430-434. doi: http://doi.org/10.1016/j.proeng.2017.03.069

Vabischevich Maksim, PhD, Department of Structural Mechanics, Kyiv National University of Construction and Architecture, Ukraine, e-mail: vabix@ukr.net, ORCID: http://orcid.org/00000002-0755-5186

Dedov Oleg, PhD, Associate Professor, Department of Machinery and Equipment of Technological Processes, Kyiv National University of Construction and Architecture,Ukraine, e-mail:dedovvcbk@ukr.net, ORCID: http://orcid.org/0000-0001-5006-772X

Glitin Oleksandr, PhD, Associate Professor, Department of Metal and Wooden Structures, Kyiv National University of Construction and Architecture,Ukraine, e-mail: glitin@ukr.net, ORCID: http:// orcid.org/0000-0003-1697-6473 